P-ISSN : 2715-744X

\title{
REPRESENTASI KELUGASAN BERANDA LAMAN WWW.COVID19.GO.ID: TINJAUAN ANALISIS WACANA KRITIS
}

\author{
Irwan Suswandi \\ Program Studi Sastra Indonesia, Fakultas Sastra, Budaya, dan Komunikasi \\ Universitas Ahmad Dahlan, Yogyakarta \\ irwanafa@gmail.com \\ DOI:
}

\begin{tabular}{|l|l|}
\hline Article Info & \multicolumn{1}{c}{ ABSTRACT } \\
Article history: & $\begin{array}{l}\text { The digital era has encourages information providers to } \\
\text { innovate by utilizing the internet to convey information quickly. No } \\
\text { exception for the government in a way to provide information and news } \\
\text { related to Covid-19 which has become a global pandemic. Using a } \\
\text { website as a source of information can give quick access for people to } \\
\text { obtain actual and valid information relating to Covid-19. Through } \\
\text { www.covid19.go.id, the government provides a facility for people to be } \\
\text { able to access all information about Covid-19 matters. In this } \\
\text { research, the researcher will analyze how government gives simplicity } \\
\text { in providing information related to Covid-19, which is represented on } \\
\text { the www.covid19.go.id homepage. The researcher used CDA (critical } \\
\text { discourse analysis) theory from Fairclough to analyze the text found } \\
\text { on the www.covid19.go.id homepage. Then, the results of critical } \\
\text { discourse analysis were linked with the reputation theory of Charles J. } \\
\text { Fombrun. The analysis produced information in the form of language } \\
\text { units of www.covid19.go.id homepage which contains a simplicity } \\
\text { matter in the delivery of information. From this analysis, the } \\
\text { researcher can conclude that the simplicity in www.covid19.go.id } \\
\text { homepage was represented through the website components, } \\
\text { content, and propositions contained in the homepage. The simplicity } \\
\text { matter also found in the use of modes, those were descriptive, } \\
\text { persuasive, and interrogative mode. }\end{array}$
\end{tabular}

Keywords: Covid-19, homepage, simplicity, text, websit 


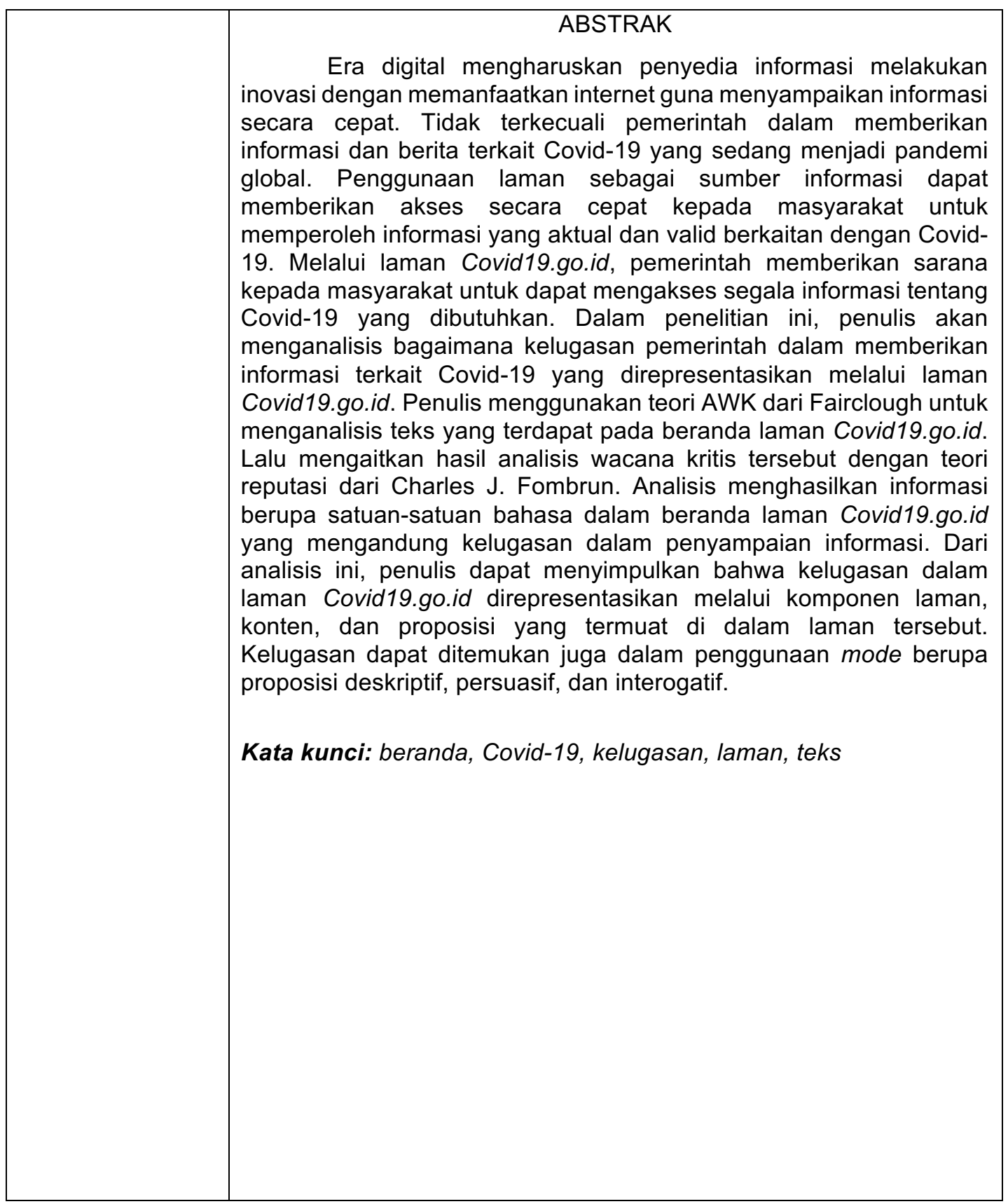

\section{PENDAHULUAN}

Kuarter pertama tahun 2020 menjadi periode yang mengejutkan bagi negaranegara di dunia. Keterkejutan yang berujung kepada kekhawatiran masyarakat dunia tersebut disebabkan oleh sebuah virus yang kini menjadi pandemi global, yaitu Covid-19 atau Coronavirus Disease 19. Penamaan corona karena virus ini masih tergolong keluarga corona, dan 19 karena merujuk 
kepada tahun kemunculannya pada tahun 2019. Sebagaimana namanya, virus ini pertama kali muncul pada tahun 2019, tepatnya 17 November 2019 di Kota Wuhan, Provinsi Hubei, China. Pasar ikan tradisional di Kota Wuhan dianggap sebagai sumber munculnya virus ini.

Semenjak satu orang terjangkit Covid-19 pada 17 November, virus ini menyebar begitu cepat di seluruh kota Wuhan. Tercatat, hingga akhir tahun 2019, terdapat 266 orang di Wuhan yang terjangkit virus mematikan ini, dengan kasus kematian pertamanya terjadi pada 11 Januari 2020. Tidak membutuhkan waktu lama bagi virus ini untuk menyebar ke luar wilayah Wuhan bahkan China. Hingga pada 13 Januari 2020 kasus pertama Covid-19 di luar China ditemukan di Thailand, yang kemudian disusul negara-negara lainnya di dunia, seperti Jepang, Amerika Serikat, dan Korea Selatan.

Di Indonesia, kemunculan virus di China dan beberapa negara di dunia dianggap tidak begitu mengkhawatirkan, karena belum adanya orang Indonesia yang terkena virus ini. Berbagai alasan dan faktor menyertai alasan mengapa virus ini tidak ditemukan di Indonesia. Atas dasar hal tersebut pula yang kemudian menjadikan pemerintah dan masyarakat Indonesia tidak begitu khawatir dengan potensi merebaknya virus ini dan aktivitas pun berjalan seperti biasa.

Hingga pada 2 Maret 2020, Indonesia digegerkan dengan ditemukannya dua pasien sekaligus menjadi kasus pertama yang terkena Covid-19 di Kota Depok, Jawa Barat. Kasus pertama tersebut kemudian disusul dengan kasus-kasus lainnya hingga menyebar hampir di seluruh provinsi di Indonesia. Dengan semakin merebaknya virus yang menyerang alat pernapasan ini, pemerintah Indonesia pun melakukan berbagai strategi untuk menanggulanginya. Salah satu langkah strategis yang dilakukan pemerintah adalah pembentukan Gugus Tugas Percepatan Penanganan Covid-19, yang mana salah satu programnya adalah pengadaan laman resmi Covid-19, yaitu www.covid19.go.id.

Laman www.covid19.go.id diresmikan pada 18 Maret 2020 dengan desain laman sedemikian rupa untuk mempermudah masyarakat dalam mengakses atau mendapatkan informasi yang diinginkan berkaitan dengan Covid-19. Keberadaan laman ini untuk menjawab informasiinformasi yang tidak akurat yang beredar di masyarakat. Ada tiga langkah yang hendak disampaikan pemerintah melalui adanya lama ini, yaitu cara mengurangi risiko penularan, cari informasi yang benar, dan apa yang perlu dilakukan bila sakit. Sebagai sumber resmi 
satu pintu dari pemerintah kepada masyarakat, kelugasan dalam memberikan informasi adalah hal mutlak yang harus dilakukan oleh pemerintah supaya tujuan dari pengadaan laman ini dapat sampai kepada masyarakat.

Bertolak dari hal itu, penulis tertarik untuk menganalisis sisi kelugasan yang dikandung dalam laman www.covid19.go.id. Penulis akan menelaah beranda laman tersebut dengan menggunakan kajian analisis wacana kritis dari Norman Fairclough. Penggunaan kajian tersebut untuk menemukan representasi kelugasan yang dimaksud dalam laman tersebut.

Permasalahan penelitian ini adalah bagaimana aspek-aspek linguistik yang terdapat pada wacana beranda laman www.covid19.go.id yang mengandung representasi kelugasan. Adapun tujuan dari penelitian ini adalah untuk menganalisis aspek-aspek linguistik yang terdapat pada wacana beranda laman www.covid19.go.id yang mengandung representasi kelugasan. Struktur wacana beserta pemilihan kosakata dalam laman akan dianalisis guna menemukan bukti linguistik dalam menjabarkan maksud kelugasan yang direpresentasikan di dalam laman tersebut.

Penulis menggunakan metode deskriptif analisis. Data akan dideskripsikan terlebih dahulu, berupa pemaparan satuan-satuan linguistik yang ditemukan di dalam wacana beranda laman www.covid19.go.id, lalu penganalisisan diperlukan untuk menemukan bentuk representasi yang dikandung di dalam satuan-satuan linguistik wacana tersebut. Sebagaimana yang disebutkan oleh Sudaryanto (1998: 68), metode deskriptif analisis bertujuan supaya analisis sematamata berdasarkan pada fakta yang ada, sehingga tujuan yang hendak dicapai terlepas dari subjektivitas penulis.

Pendekatan dalam penelitian ini adalah pendekatan dari perspektif analisis wacana kritis (AWK) Norman Fairclough, dengan disertai teori reputasi dari Charles J. Fombrun. AWK dari Fairclough dikenal juga sebagai model perubahan sosial. Di dalamnya, terdapat perspektif, yaitu communication events dan the order of discourse. Untuk kajian wacana yang melibatkan teks, communication events menjadi perspektif yang digunakan oleh penulis karena di dalamnya terkandung tiga dimensi dalam proses AWK, yaitu teks, praktik diskursif atau praktik wacana, dan praksis sosio-budaya (Fairclough, 1995: 97).

Dimensi teks berkaitan dengan segala hal yang berhubungan dengan bentuk linguistik teks, yang meliputi bentuk wicara, tulisan, grafik, dan kombinasinya. Adapun dimensi 
praktif diskursif adalah segala hal yang berhubungan dengan bentuk produksi dan konsumsi teks, yang di dalam proses menghubungkannya sudah ada interpretasi. Lalu, dimensi praksis sosial budaya adalah segala hal yang berada di luar teks, yaitu berkaitan tujuan, jaringan, dan praksis sosial budaya yang lebih luas, yang di dalamnya sudah ada pemahaman intertekstual. Ketiga dimensi dalam perspektif communication events AWK dapat diterangkan dalam gambar berikut.

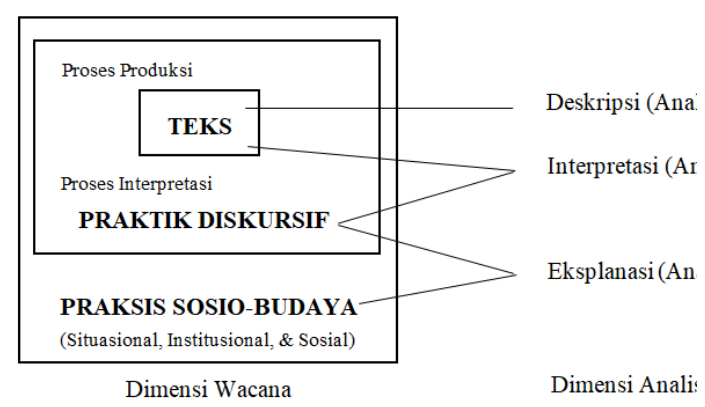

Pada dimensi teks, satuan-satuan yang dapat dianalisis adalah kata, frasa, klausa, hingga kalimat, serta memperhatikan kohesi dan koherensi guna menemukan makna yang hendak disampaikan teks tersebut kepada pembaca. Di dalam dimensi ini, terdapat tiga elemen dasar, yaitu representasi, identitas, dan relasi. Dalam hal ini, penulis akan berfokus pada elemen representasi, karena berkaitan dengan bagaimana seseorang, kelompok, tindakan, dan kegiatan ditampilkan dalam wujud teks. Penulis akan menelaah bagaimana tindakan lugas dari kelompok, dalam hal ini pemerintah, yang ditampilkan melalui satuan-satuan teks dalam beranda laman www.covid19.go.id.

Teori reputasi dari Fombrun mengatakan bahwa suatu korporat, termasuk di dalamnya pemerintah, harus memiliki empat hal supaya memperoleh reputasi yang baik, yaitu credibility (kredibilitas di mata investor), reliability (keterandalan di mata konsumen), trustworthiness (terpercaya dalam pandangan karyawan), dan responsibility (tanggung jawab sosial terhadap komunitas masyarakat) (Fombrun, 1996: 143). Keempat hal berkaitan reputasi tersebut dapat digambarkan sebagai berikut.

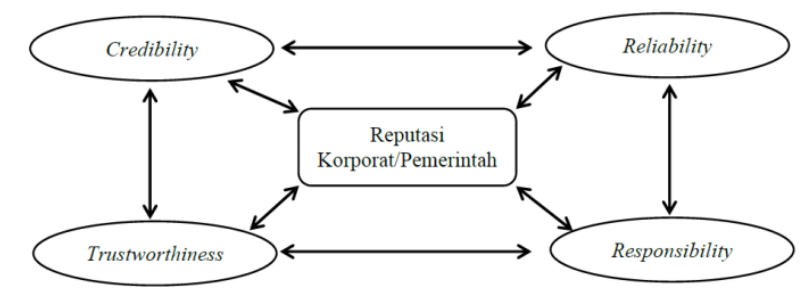

Sebagai salah satu hal yang memengaruhi reputasi, keterandalan atau reliability pemerintah didasarkan pada kepuasaan masyarakat terhadap produk atau jasa yang ditawarkan. Masyarakat mengharapkan kualitas dan keterandalan dari suatu program atau kebijakan pemerintah yang lebih baik dari kompetitor lainnya, yang dalam hal ini dapat dikatakan dari pihak nonpemerintah atau swasta. 
Dalam sisi keterandalan, tentu mengandung unsur-unsur yang menjadi pertimbangan sesuatu akan diandalkan atau tidak. Berkaitan dengan produk informasi, dalam hal ini laman mengenai Covid-19, salah satu unsur yang dapat menjadi pertimbangan masyarakat untuk menjadikan produk tersebut dapat diandalkan atau tidak adalah dari sisi kelugasannya dalam menyampaikan informasi. Masyarakat menginginkan suatu produk informasi berisi informasi-informasi yang lugas, yang tidak berbelit-belit dan disampaikan dengan secara sederhana sehingga mudah dipahami.

Masyarakat mengharapkan pada saat mengakses suatu laman, maka mereka dapat langsung menemukan apa yang mereka cari. Begitu pun pemerintah selaku pihak penyedia informasi, maka akan berusaha memberikan informasi selugas mungkin berkaitan dengan informasi yang sedang banyak ingin diketahui oleh masyarakat. Kamus Besar Bahasa Indonesia Edisi V menyebutkan komponenkomponen di dalam pemaknaan kata 'lugas', yaitu meliputi (a) pokok-pokok yang penting saja; (b) apa adanya; (c) serba sederhana; (d) tidak berbelit-belit; dan (d) tidak bersifat pribadi atau objektif.

Untuk menganalisis representasi kelugasan dalam beranda laman www.covid19.go.id, maka bahan yang dipakai dalam penelitian ini adalah satuan-satuan bahasa yang terdiri dari kata, frasa, klausa, kalimat, dan paragraf di dalam beranda laman www.covid19.go.id. Ada dua sumber data yang digunakan, yaitu data primer dan sekunder. Data primer dalam penelitian ini adalah laman http://www.covid19.go.id yang peneliti akses pada 26 April 2020 pukul 11.25 WIB. Untuk mendukung penelitian ini, penulis menggunakan data sekunder berupa studi kepustakaan yang dapat menunjang data dalam menjawab permasalahan penelitian.

\section{PEMBAHASAN}

Setelah melakukan pengumpulan dan pengolahan data, maka dapat dilakukan penganalisisan representasi kelugasan dalam beranda laman www.covid19.go.id sebagai berikut.

\section{- Identifikasi Komponen Laman www.covid19.go.id}

Sebelum masuk ke dalam pembahasan mengenai representasi yang dikandung dalam laman www.covid19.go.id, maka perlu dilakukan pengelompokkan data berdasarkan penamaan komponen laman untuk mempermudah dalam menganalisis data. Pengelompokkan berdasarkan komponen laman juga dapat mengindikasikan jenis 
komponen yang ingin ditonjolkan oleh laman tersebut.

Laman www.covid19.go.id memiliki tujuh komponen sebagai website atau laman, yaitu nama domain, header, navbar, menu, konten, social media button, dan footer.

a. Nama domain www.covid19.go.id

b. Header

Pertanyaan? COVID-19 Hotline 119

c. Navbar dan Menu

Navbar atau navigation bar dan Menu dalam laman ini memiliki bentuk yang sama, yaitu meliputi Berita, Sebaran, Protokol, Edukasi, Tanya Jawab, Agenda, Hoaks Buster. Dalam laman ini, setiap komponen Menu ditampilkan dalam bentuk tautan-tautan yang dapat langsung dipilih oleh pengunjung laman. Satu Menu laman dapat terdiri dari satu sampai tiga tautan, yang akan dibahas lebih mendalam dalam pembahasan representasi.

d. Konten

Konten dalam halaman beranda laman www.covid19.go.id berbentuk tautantautan yang ada dalam setiap menu, kecuali pada Menu Edukasi, yang mana konten ditampilkan dalam bentuk video ilustrasi disertai dengan sebuah takarir.
Selain itu, di samping keberadaan Menu sebagai kontennya, dalam halaman beranda laman ini ditampilkan pula: (a) headline dengan tiga gambar latar belakang berukuran besar dengan disertai judul yang bergantian secara otomatis yang mengarah ke suatu tautan di halaman lainnya dalam laman tersebut, dan (b) dua tautan di atas headline yang mengarah kepada halaman lainnya.

e. Social Media Button

Instragam

Follow on Instagram

f. Footer

Copyright@2020 Badan Nasional Penanggulangan Bencana All rights reserved

Berkaitan dengan representasi kelugasan, maka penulis hanya akan berfokus pada satuan bahasa yang digunakan dalam header, konten, dan menu.

- Representasi Beranda Laman www.covid19.go.id

\begin{tabular}{|l|}
\hline \multicolumn{1}{|c|}{ Header } \\
\hline Pertanyaan? COVID-19 Hotline 119 \\
\hline Analisis: \\
$\underline{\text { Dimensi Teks }}$ \\
\hline
\end{tabular}




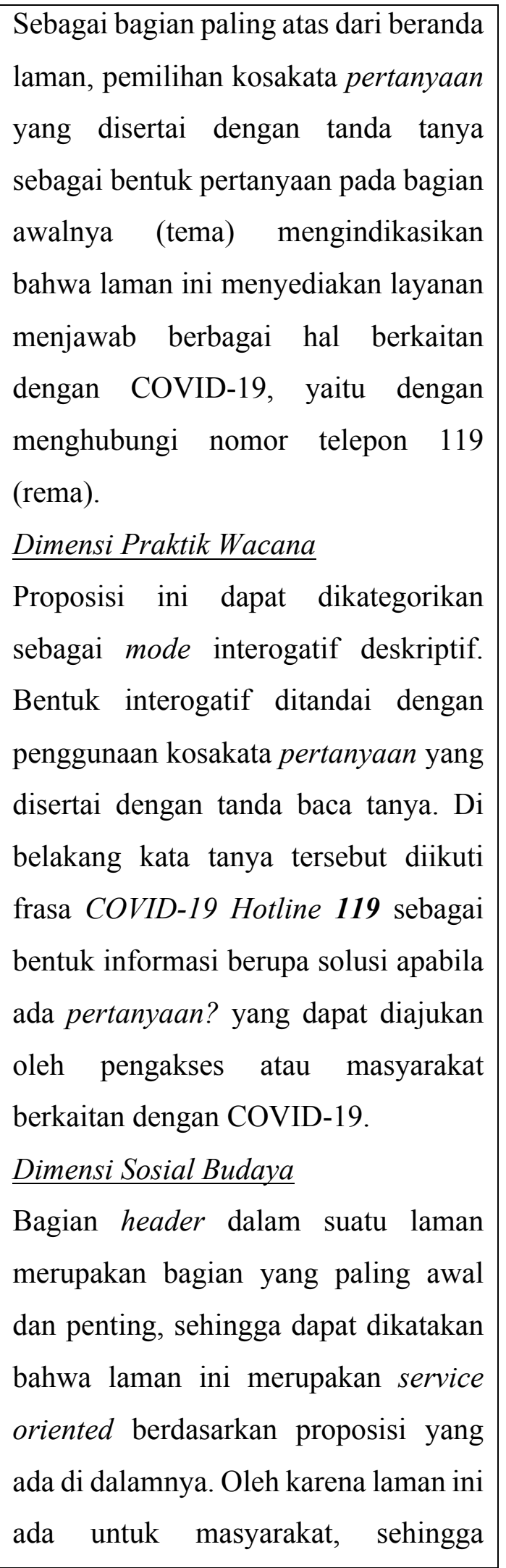

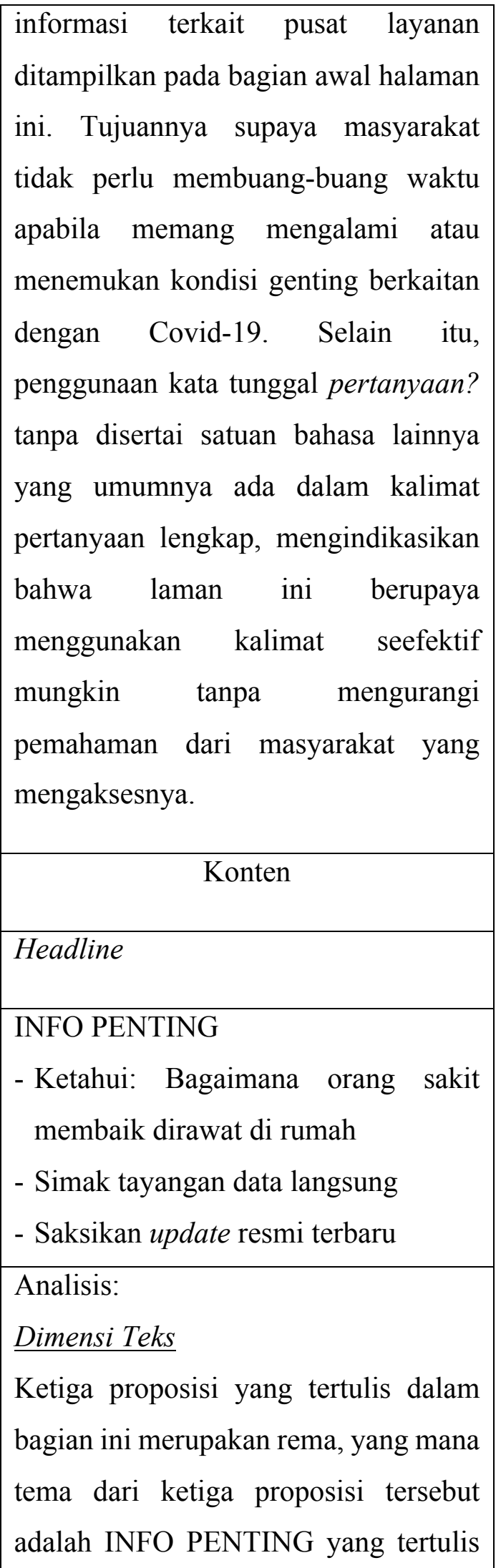




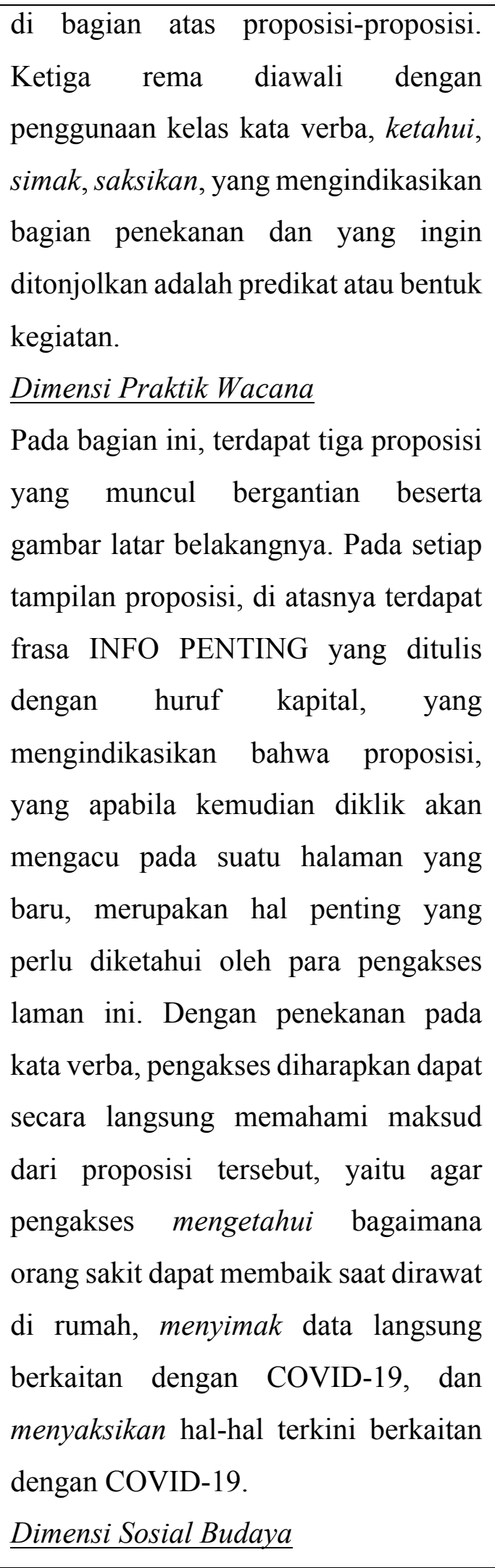

Pemilihan kata ketahui pada proposisi pertama dapat dimaknai bahwa masih ada pengakses atau masyarakat yang tidak mengetahui bagaimana orang sakit membaik dirawat di rumah. Penempatan proposisi ini sebagai headline dalam laman menandakan bahwa informasi terkait merawat orang sakit di rumah sangat diperlukan supaya masyarakat dapat melakukan penanganan medis pertama kepada anggota keluarga mereka tanpa harus pergi rumah sakit atau melakukan bepergian ke luar rumah. Begitu pun dua proposisi lainnya pemilihan kata simak data dan saksikan update sebagai bagian dalam headline mengindikasikan bahwa masyarakat perlu menyimak dan menyaksikan data dan berita terbaru terkait COVID-19.

- Pesan Presiden: Satu Visi dan Strategi Tangani Covid-19

Analisis:

\section{Dimensi Teks}

Proposisi ini diawali dengan frasa nomina Pesan Presiden sebagai tema, yang menandakan bahwa pesan presiden ini menjadi bagian inti dari proposisi yang diharapkan dapat diperhatikan oleh pengakses atau 
masyarakat. Di belakang frasa ini tertuliskan Satu Visi dan Strategi Tangani Covid-19 sebagai rema yang mengindikasikan bahwa bagian penting dari proposisi berupa Pesan Presiden adalah berkaitan dengan visi dan strategi yang sama dalam menangani Covid-19.

\section{Dimensi Praktik Wacana}

Proposisi di atas dikategorikan dalam mode persuasif, yang bermakna mengandung ajakan kepada pengakses atau masyarakat untuk bersama-sama dalam satu visi dan strategi dalam menangani COVID-19. Proposisi dalam bentuk persuasi dimaksudkan supaya masyarakat patuh dan taat kepada presiden, yang mewakili pemerintah, berkaitan dengan visi-visi dan strategi-strategi pemerintah dalam upaya menangani COVID-19.

\section{Dimensi Sosial Budaya}

Penggunaan kata satu dalam rema proposisi mengandung arti bahwa di dalam masyarakat masih banyak pengakses atau masyarakat yang tidak sejalan dengan pemerintah terkait penanganan COVID-19. Pemilihan kosakata yang membentuk proposisi ini dilakukan secara efektif, seperti pemilihan kata tangani alih-alih yang baku adalah menangani.

Ketahui: Cara Menggunakan masker yang tepat

Analisis:

Dimensi Teks

Proposisi diawali dengan penggunaan kelas kata verba ketahui yang sekaligus sebagai tema dari proposisi tersebut, yang mengindikasikan bagian itu adalah bagian inti dari proposisi yang kemudian disertai dengan informasi yang ingin disampaikan, yaitu rema, berupa cara menggunakan masker yang tepat. Penggunaan kata ketahui sebagai tema menjadi penekanan bahwa pengakses atau masyarakat perlu mengetahui informasi yang disampaikan tersebut.

Dimensi Praktik Wacana

Pemilihan kata ketahui di bagian awal proposisi ini memiliki mode persuasif yang mengajak pengaksesnya untuk tahu mengenai cara menggunakan masker yang tepat. Penggunaan kata ketahui dimaksudkan supaya nantinya pengakses apabila mengklik tautan berupa proposisi ini akan menjadi tahu mengenai penggunaan masker yang 


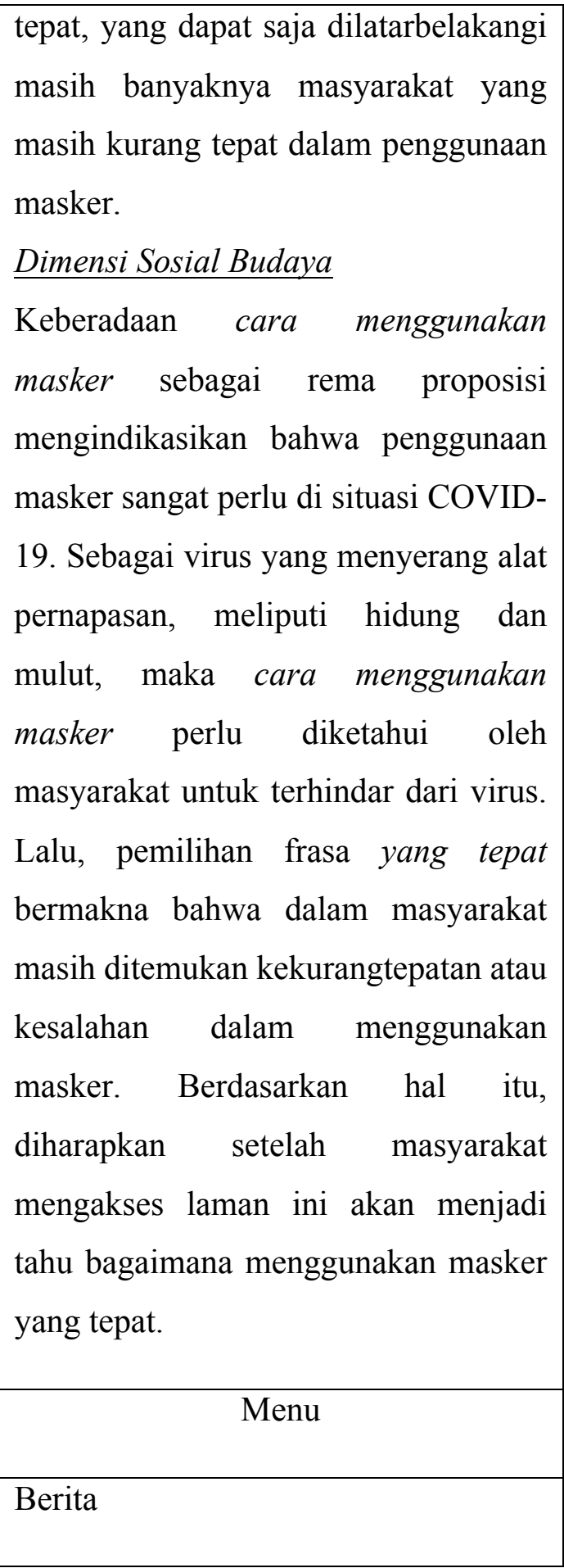

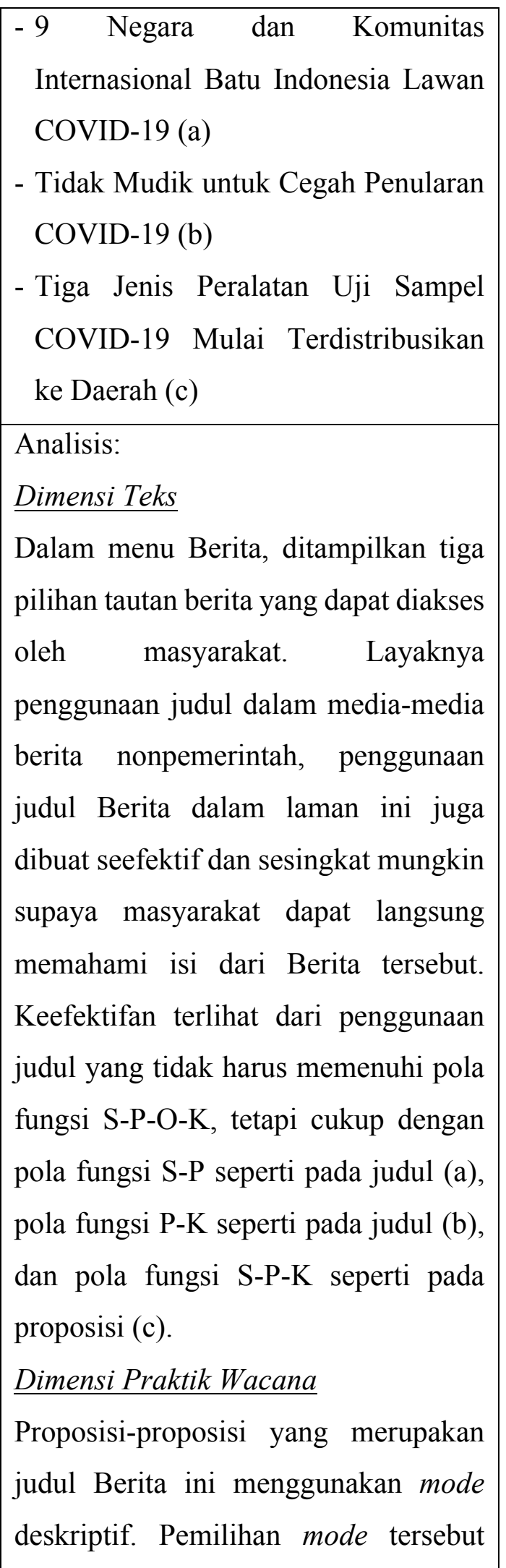




\section{disesuaikan dengan proposisi tersebut yang merupakan judul dari suatu berita. Sebagai bentuk deskriptif, maka tujuan dari proposisi judul Berita ini adalah apabila masyarakat mengklik tautan akan mengetahui informasi terkait berita yang sedang dibahas. \\ Dimensi Sosial Budaya \\ Situasi yang terjadi akibat COVID-19 memberikan dampak keingintahuan masyarakat terkait dengan berita-berita yang sedang terjadi berkaitan dengan COVID-19. Pada tiga proposisi dalam Menu Berita ini, keberadaan kata COVID-19 menjadi pembahasan utama yang dibahas dalam masing-masing berita, sebagaimana sesuai dengan tujuan dari laman ini.}

\section{Data Sebaran}

\section{Global}

Negara/Kawasan

213

Kasus Terkontaminasi

2.724.809

Kematian

187.847

WHO Data Last update 25 April 2020, 07:00 GMT+7

Indonesia

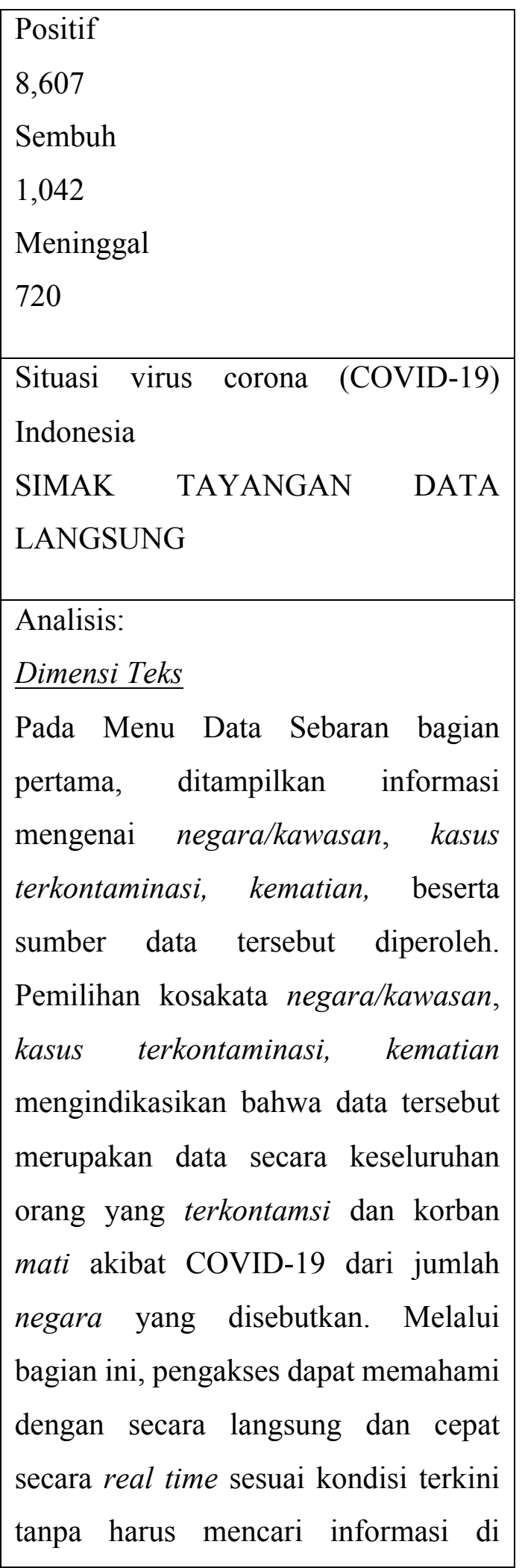


sumber-sumber berita di laman yang lainnya.

Pada bagian kedua dari Menu Data Sebaran, ditampilkan informasi data terkini berkaitan dengan jumlah yang berada di Indonesia. Pemilihan kosakata positif, sembuh, dan meninggal untuk merepresentasikan jumlah orang yang sudah dipastikan terkena COVID-19, orang yang berhasil sembuh dari COVID-19, dan jumlah korban meninggal dunia akibat COVID-19. Kosakata dipilih seefektif mungkin dengan cukup menggunakan kosakata positif, sembuh, dan meninggal tanpa penambahan satuan bahasa lainnya, demi menonjolkan data sebagai bagian penting dari laman ini. Pada bagian ketiga Menu Data Sebaran ini, penggunaan klausa Situasi virus corona (COVID-19) Indonesia dan Simak Tayangan Data Langsung memberitahukan kepada pengakses bahwa mereka dapat menyaksikan tayangan yang berisi data langsung mengenai situasi COVID-19 yang ada di Indonesia. Pemilihan kata Simak Tayangan bermakna pengakses dapat dengan cara menonton data dalam bentuk tayangan atau video apabila

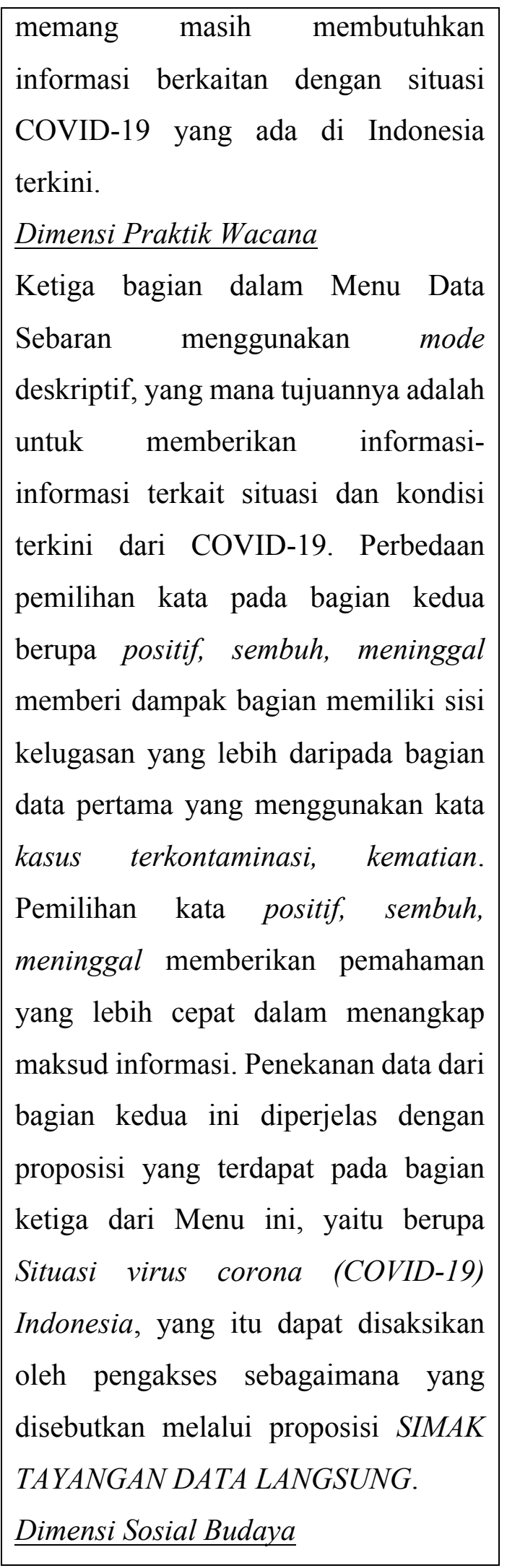




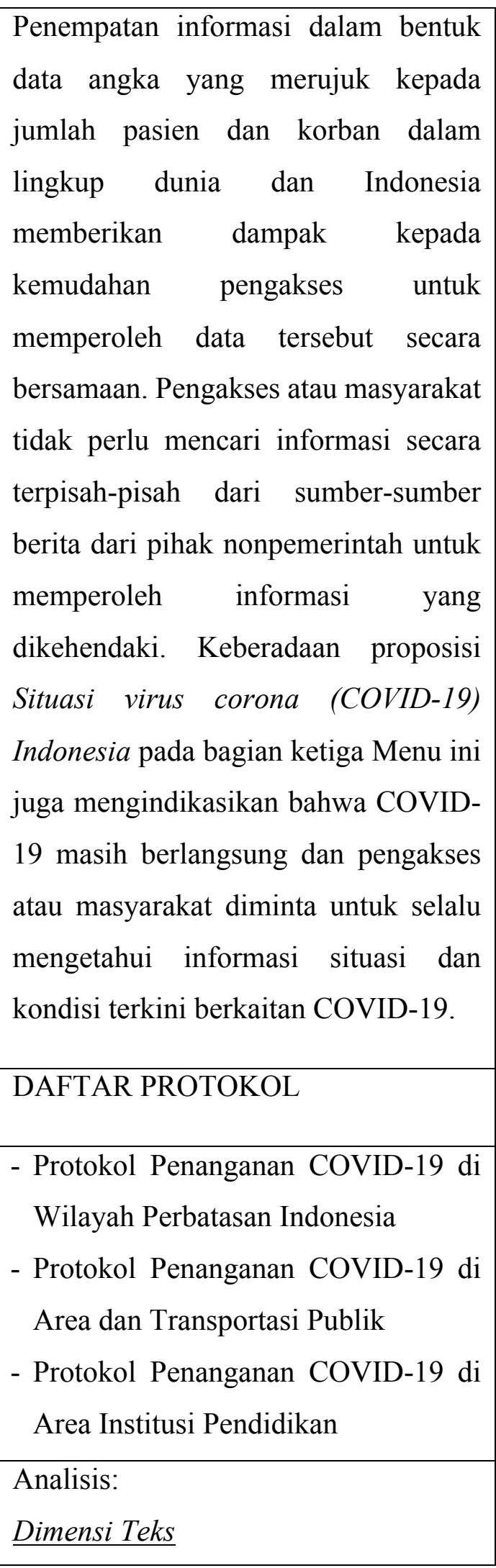

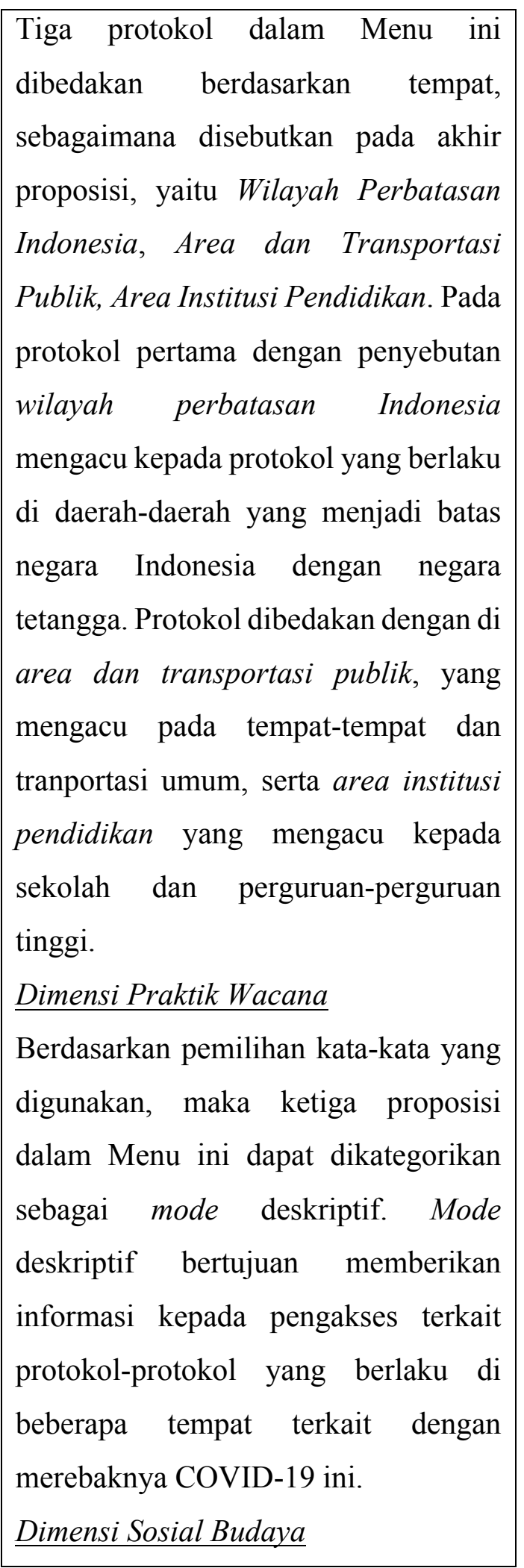

Tiga protokol dalam Menu ini dibedakan berdasarkan tempat, sebagaimana disebutkan pada akhir Indonesia, Area dan Transportasi Publik, Area Institusi Pendidikan. Pada protokol pertama dengan penyebutan mengacu kepada protokol yang berlaku di daerah-daerah yang menjadi batas negara Indonesia dengan negara tetangga. Protokol dibedakan dengan di area dan transportasi publik, yang mengacu pada tempat-tempat dan tranportasi umum, serta area institusi pendidikan yang mengacu kepada

Berdasarkan pemilihan kata-kata yang digunakan, maka ketiga proposisi dalam Menu ini dapat dikategorikan sebagai mode deskriptif. Mode informasi kepada pengakses terkait protokol-protokol yang berlaku di merebaknya COVID-19 ini.
$\underline{\text { Dimensi Sosial Budaya }}$ 
Sebagaimana tujuan dari laman ini untuk memberikan kemudahan dan kecepatan dalam memberikan informasi terkait COVID-19, maka protokol dibedakan sesuai dengan lokasi yang tidak memiliki kedekatan atau persamaan. Dalam hal ini pada protokol kedua, dengan frasa area publik dan transportasi publik memiliki keterkaitan tempat sehingga dijadikan dalam satu proposisi dan protokol. Adapun protokol kedua dengan frasa wilayah perbatasan Indonesia dan ketiga dengan frasa area institusi pendidikan dipisahkan dalam protokol tersendiri karena kekhususan lokasinya, yang berbeda dibandingkan dengan lokasi publik. Pengakses dapat secara mudah bagian protokol mana yang ingin dicarinya dengan memperhatikan judul dari tiap-tiap protokol tersebut.

\section{TANYA JAWAB}

Apakah saya sebaiknya menggunakan masker?

Analisis:

\section{Dimensi Teks}

Kalimat pertanyaan ini mengandung makna apakah masker perlu digunakan atau tidak oleh pengakses. Kalimat pertanyaan ini muncul di bagian pertama dari Menu TANYA JAWAB yang mengindikasikan pertanyaan ini adalah pertanyaan yang paling banyak ditanyakan oleh pengakses, dan selanjutnya pengakses lain yang hendak bertanya dengan pertanyaan serupa dapat langsung mengetahui jawabannya dengan mengklik tautan proposisi tersebut.

\section{Dimensi Praktik Wacana}

Proposisi ini termasuk mode interogatif yang menanyakan mengenai apakah penggunaan masker penting atau tidak. Pemilihan kata tanya apakah bermakna bentuk kepastian dari suatu hal yang masih membuat bingung di dalam masyarakat.

\section{Dimensi Sosial Budaya}

Penggunaan kosakata sebaiknya merujuk kepada suatu hal yang semestinya dilakukan karena memiliki kebermanfaataan apabila sesuatu tidak dilakukan. Keberadaan kosakata tersebut yang diawali dengan kata tanya apakah menandakan bahwa dalam masyarakat masih terdapat kegalauan dalam menggunakan masker dalam situasi di tengah wabah COVID- 


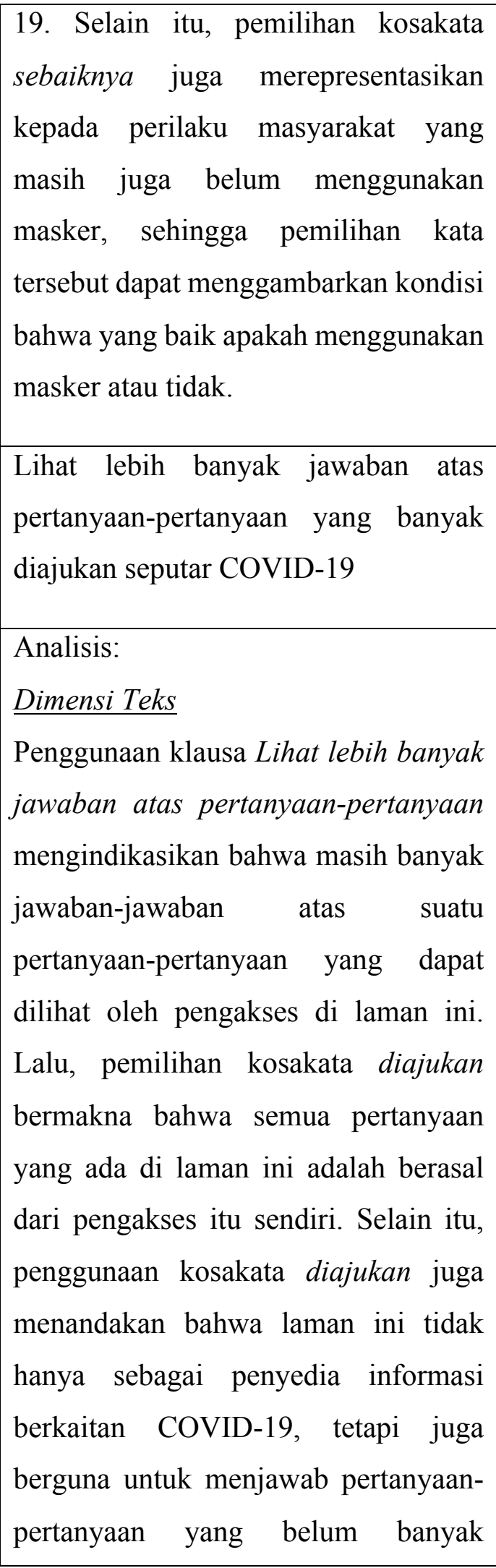

masyarakat ketahui mengenai COVID19.

\section{Dimensi Praktik Wacana}

Proposisi ini dikategorikan ke dalam mode persuasif karena terdapat penggunaan kata lihat dalam klausa lihat lebih banyak jawaban yang bermakna pengakses atau masyarakat diajak untuk membaca jawababjawaban lain yang banyak ditanyakan terkait COVID-19.

\section{Dimensi Sosial Budaya}

Keberadaan frasa banyak diajukan menandakan bahwa pengakses atau masyarakat masih banyak yang tidak mengerti hal yang berkaitan dengan COVID-19. Oleh karenanya, jawabanjawaban atas pertanyaan yang diajukan terkumpulkan menjadi satu untuk kemudian dapat dilihat oleh pengakses lainnya, sehingga pengakses atau masyarakat tidak perlu lagi menanyakan pertanyaan serupa.

HOAKS BUSTER

[SALAH] Tidak Ada Pasien Positif Corona di Aceh

[SALAH] Video "nasehat dari alm. Erma Yunita Simamora yg meninggal 
pd tanggal. 20-04-2020 di RS AR Bunda Lbk Linggau

Analisis:

\section{Dimensi Teks}

Pemilihan kata buster setelah kata hoaks mengindikasikan keberadaan Menu ini dalam laman berguna untuk menangkis berita-berita hoaks atau palsu yang beredar di masyarakat berkaitan dengan COID-19.

\section{Dimensi Praktik Wacana}

Proposisi-proposisi dalam Menu ini dapat dikategorikan ke dalam mode deskriptif. Bentuk deskriptif dapat dilihat pada pemilihan kata dalam proposisi yang memberitahu kepada pengakses atau masyarakat terkait isuisu yang sedang beredar dalam masyarakat. Pada bagian Menu ini, di bagian awal dari judul informasi (proposisi) disematkan kata SALAH, dengan huruf kapital dan berada di dalam tanda kurung. Penggunaan kata SALAH mengindikasikan bahwa informasi berupa Tidak Ada Pasien Positif Corona di Aceh dan Video "nasehat dari alm. Erma Yunita Simamora yg meninggal pd tanggal. 20-04-2020 di RS AR Bunda Lbk Linggau adalah salah dan hoaks semata. Penempatan kata SALAH di bagian depan judul juga berfungsi supaya pengakses yang membuka laman ini dapat secara langsung paham dan mengerti bahwa informasiinformasi tersebut adalah salah.

\section{Dimensi Sosial Budaya}

Pemilihan kata Hoaks Buster dalam laman ini dapat menjadi indikasi bahwa banyaknya berita tidak benar mengenai COVID-19 yang beredar di dalam masyarakat, dan tidak sedikit pula masyarakat yang percaya dengan berita-berita palsu tersebut. Selain itu, penyematan kata SALAH pada bagian awal proposisi juga untuk menegaskan kepada pengakses atau masyarakat secara langsung saat membaca proposisi tersebut bahwa berita tersebut adalah hoaks semata.

\section{EDUKASI}

Pengetahuan adalah segalanya. Pastikan berbagi informasi yang benar dengan keluarga, kerabat, rekan kerja dan lingkungan Anda. Mulai beraksi sekarang.

Virus Corona COVID-19

Lindungi Diri Lindungi Sesama

Analisis: 
Bagian teks dalam Menu ini diawali dengan proposisi pengetahuan adalah segalanya. Dapat dimaknai bahwa pengetahuan memiliki posisi yang sangat penting dan berkaitan dengan segala hal. Lalu, proposisi berikutnya diawali dengan klausa pastikan berbagi informasi yang benar yang bermakna bahwa pengetahuan berupa informasi yang benar semestinya dibagikan, sehingga akan banyak orang yang tahu dari pengetahuan yang kita miliki. Proposisi selanjutnya adalah mulai beraksi sekarang, yang bermakna bahwa waktu untuk membagikan informasi yang benar dari pengetahuan yang kita miliki adalah semestinya dilakukan saat ini, sekarang juga, tidak perlu ditunda-tunda.

\section{Dimensi Praktik Wacana}

Teks di atas dapat dikategorikan ke dalam mode persuasif dengan penggunaan frasa pastikan berbagi, serta klausa mulai beraksi sekarang dan lindungi diri lindungi sesama. Bentuk persuasif yang digunakan dalam teks ini bermakna setelah masyarakat mengakses berbagai informasi yang ada dalam laman ini, maka dapat membagikannya kepada yang lainnya yang tidak mengakses laman ini.

\section{Dimensi Sosial Budaya}

Pemilihan frasa yang benar mengandung makna bahwa di dalam masyarakat masih terdapat informasiinformasi yang tidak benar atau hoaks. Oleh karena masih adanya informasiinformasi yang tidak benar, maka pengakses atau masyarakat diajak untuk membagikan informasi benar yang dimilikinya kepada orang-orang lain. Dimulai dari lindungi diri (melindungi diri sendiri) baru dapat lindungi sesama (melindungi anggota masyarakat lain).

Sayangi Keluarga di Kampung. Lebih Baik Silaturahmi Digital

Analisis:

Dimensi Teks

Salah satu pengetahuan yang dapat dimiliki oleh pengakses adalah mengenai Sayangi Keluarga di Kampung. Lebih Baik Silaturahmi Digital. Pemilihan frasa lebih baik bermakna bahwa silaturahmi secara digital kepada keluarga yang ada di kampung memiliki dampak dan manfaat yang lebih dibandingkan harus 
bersilaturahmi secara langsung di tengah kondisi COVID-19 seperti sekarang ini.

Dimensi Praktik Wacana

Proposisi ini dapat dikategorikan sebagai mode persuasif dengan penggunaan kata sayangi yang bermakna mengajak pengakses atau masyarakat untuk menyayangi keluarga yang berada di kampung. Dengan cara apa? Dengan bersilaturahmi secara digital, tidak tatap muka secara langsung.

\section{Dimensi Sosial Budaya}

Proposisi di atas bermakna bahwa silaturahmi kepada keluarga secara di kampung dalam situasi COVID-19 adalah bentuk tidak menyayangi keluarga. Bentuk sayang kepada keluarga di kampung dalam situasi ini adalah dengan melalui silaturahmi melalui digital atau teknologi, tidak tatap muka secara langsung. Penggunaan proposisi dalam Menu ini dapat bermakna pula bahwa masyarakat masih ada yang memaksakan pulang ke kampung dalam kondisi merebaknya COVID-19. Oleh karena itu, penggunaan proposisi Sayangi Keluarga di Kampung. Lebih
Baik Silaturahmi Digital dapat menjadi solusi mengedukasi masyarakat bahwa tindakan mereka untuk pulang kampung adalah tidak baik.

\section{- Kelugasan Beranda Laman}

\section{Covid19.go.id}

Sebagaimana yang telah disebutkan pada bagian awal, salah satu hal yang membentuk reputasi baik adalah keterandalan di mata konsumen. Dalam hal ini, laman www.covid19.go.id sebagai produk dari pemerintah akan memiliki reputasi baik apabila laman ini dapat diandalkan dalam memberikan informasi terkait Covid-19.

Salah satu unsur yang menjadi pertimbangan produk informasi ini dapat diandalkan di mata konsumen (selanjutnya akan disebut masyarakat) adalah kejelasan dan kegamblangan dalam menyampaikan informasinya. Bukan sebaliknya, informasi disampaikan secara berbelitbelit dan berputar-putar yang menjadikan masyarakat bukannya menjadi tahu dan paham, melainkan sebaliknya. Atau dapat dikatakan, produk informasi yang ditawarkan memiliki kelugasan di dalamnya. Laman www.covid19.go.id 
sebagai produk informasi dari pemerintah yang berfokus pada Covid-19 memiliki kelugasan yang dapat direpresentasikan dari beberapa hal, yaitu dari komponen laman, dari konten, dan dari satuan-satuan bahasa yang digunakan.

Dari segi komponennya, tampilan beranda laman www.covid19.go.id hanya terdiri dari header, menu, nabvbar, konten, social media button, dan footer. Padahal dapat saja komponen ini dapat ditambahkan untuk memperpadat tampilan beranda. Namun, tampilan halaman yang minimalis yang menonjolkan komponen konten, sebagai komponen yang paling banyak ditampilkan, memiliki maksud laman ini ingin memaksimalkan konten yang mereka miliki. Pengakses laman diharapkan dapat langsung memperoleh banyak pilihan informasi pada saat pertama kali mengakses laman ini.

Begitu pun dengan pilihan Menu yang menjadi Konten dalam laman ini, yang kesemuanya mengandung informasi yang sangat informatif dan padat terkait dengan Covid-19 ini, yaitu meliputi Berita, Sebaran, Protokol, Edukasi, Tanya Jawab, Agenda, dan Hoaks Buster.

Dari segi kontennya, beranda laman www.covid19.go.id memiliki sisi deskriptif, sekaligus persuasif terkait dengan Covid-19 yang sedang merebak. Konten-konten yang termuat di dalam beranda laman ini adalah hal-hal yang diperlukan dan dibutuhkan oleh masyarakat terkait situasi yang diakibatkan oleh Covid-19.

Dari segi satuan bahasanya, ditemukan empat bentuk kelugasan yang dapat ditemukan dalam laman www.covid19.go.id, yaitu sebagai berikut. (a) Pelesapan (deletion) konstituen pembentuk konstruksi utuh

Bentuk kelugasan pertama dalam laman www.covid19.go.id adalah ditemukannya satuan-satuan bahasa yang dilesapkan untuk menampilkan sisi efektivitas dan keringkasan dalam menyampaikan informasi. Pelesapan ini dilakukan karena ada tidaknya satuan bahasa yang dilesapkan, masih memiliki makna yang dapat dipahami oleh pengakses.

Bentuk pelesapan satuan bahasa yang dapat ditemukan dalam laman ini adalah Pertanyaan?; COVID-19 Hotline 119; Negara/Kawasan; Kasus Terkontaminasi; Kematian; Positif; Sembuh; Meninggal. Apabila dituliskan dalam konstruksi yang utuh, maka satuan-satuan bahasa tersebut semestinya ditulis Ada Pertanyaan?; 
Hubungi COVID-19 Hotline 119;

Jumlah Negara/Kawasan Terdampak;

Jumlah Kematian; Jumlah Pasien

Positif; Jumlah Pasien Sembuh;

Jumlah Pasien Meninggal.

Namun begitu, tidak adanya konstituen tersebut tidak memengaruhi makna yang disampaikan. Oleh karenanya, demi efisiensi untuk memberikan informasi yang lugas, maka dituliskan konstituen utama saja sehingga masih tetap dipahami oleh pengakses.

(b) Pembentukan proposisi-proposisi atas dua fungsi kata

Bentuk kelugasan lainnya yang ditemukan dalam laman www.covid19.go.id adalah pembentukan proposisi yang hanya terdiri dari dua fungsi kata. Pola kalimat ini banyak ditemukan dalam laman, yaitu pada Simak tayangan data langsung; Saksikan update resmi terbaru; Tidak Mudik untuk Cegah Penularan COVID-19; Sayangi Keluarga di Kampung. Pola kalimat proposisi tersebut adalah $\mathrm{P}-\mathrm{O}$ (Predikat-Objek); P-O (PredikatObjek); P-Pel (Predikat-Pelengkap); $\mathrm{P}-$ Ket (Predikat-Keterangan).
Penggunaan dua pola kalimat tersebut untuk efisiensi satuan bahasa, yaitu menampilkan pola terkecil dari proposisi tanpa mengubah atau memengaruhi makna yang ingin disampaikan. Selain efisiensi dalam pemilihan pola struktur kalimat, pada proposisi Simak tayangan data langsung; Saksikan update resmi terbaru juga terindikasi adanya pelesapan atas satuan bahasa yang lebih lengkap, alih-alih dapat ditambahkan data jumlah pasien, atau data persebaran wilayah terdampak, dan sebagainya; serta setelah kata update, yang alih-alih dapat ditambahkan dengan update data jumlah pasien, atau update data persebaran wilayah terdampak, dan sebagainya.

(c) Pemilihan kata nonbaku

Beberapa satuan bahasa dalam laman www.covid19.go.id ditemukan bentuknya sebagai kata yang tidak baku (sesuai dengan kata turunan dalam KBBI V). Satuan-satuan bahasa tersebut adalah tangani; ketahui; lindungi; dan sayangi. Dalam KBBI V, kata-kata tersebut tidak ditemukan, alih-alih yang sesuai adalah 
menangani; mengetahui; melindungi; dan menyayangi.

Meskipun begitu, sebagaimana dalam bahasa Indonesia ragam jurnalistik, penggunaan kata-kata tersebut lazim digunakan dalam masyarakat dan memiliki kelugasan dan keringkasan dalam menyampaikan maksud yang sama dengan menangani; mengetahui; melindungi; dan menyayangi. Pemilihan kata-kata nonbaku tersebut untuk mengefektifkan maksud untuk menciptakan proposisi dalam laman yang lebih singkat dan padat.

(d) Penggunaan huruf kapital

Bentuk kelugasan yang terakhir yang dapat ditemukan dalam laman www.covid19.go.id adalah penggunaan huruf kapital di beberapa proposisi sebagai bentuk penegasan atas informasi yang disampaikan. Penggunaan kapital tersebut di antaranya INFO PENTING; SIMAK TAYANGAN DATA LANGSUNG; [SALAH]. Pemilihan proposisi yang disematkan huruf kapital di dalamnya adalah didasarkan pada informasi yang hendak ditekankan oleh pemroduksi teks terkait dengan Covid-19.

\section{KESIMPULAN}

Dari analisis yang telah dilakukan terhadap beranda laman www.covid19.go.id, diperoleh kesimpulan berkaitan dengan representasi kelugasan.

1. Representasi kelugasan dalam teks yang terdapat pada beranda laman www.covid19.go.id tersebar hampir di seluruh bagian beranda. Kelugasan dalam teks terlihat dalam pemilihan kosakatakosakata yang menyusun proposisi dalam laman. Hubungan antara tema-rema dalam proposisi juga berperan dalam memberikan kelugasan yang ingin disampaikan dari pembuat laman kepada pengaksesnya.

2. Proposisi-proposisi dalam laman menggunakan mode deskriptif, persuasif, dan interogatif. Mode deskriptif berkaitan dengan penyantuman proposisi yang bersifat informatif, menyampaikan informasi apa adanya; mode persuasif berkaitan proposisi dalam teks yang bersifat mengajak dan imbauan kepada pengakses untuk melakukan suatu hal; dan mode interogatif berkaitan dengan pertanyaan yang bersifat ke penekanan yang kemudian dijawab dalam rema proposisi tersebut. 
3. Bentuk kelugasan laman dapat dilihat dari tiga segi, yaitu segi komponen laman, segi konten laman, dan segi satuan bahasa.

4. Kelugasan dari segi satuan bahasa dapat ditemukan dalam empat bentuk, yaitu (a) pelesapan (deletion) konstituen pembentuk konstruksi utuh; (b) pembentukan proposisi-proposisi atas dua fungsi kata; (c) pemilihan kata nonbaku; dan (d) penggunaan huruf kapital.

\section{DAFTAR PUSTAKA}

Fairclough, Norman. Language and Power. Edisi Kedua. London. Longman. 2001.

\section{- Critical Discourse} Analysis: The Critical Study of Language. New York. Longman Publishing. 1995

Fombrun, Charles J. Reputation: Realizing Value from the Corporate Image. Massachusetts: Harvard Business School Press. 2018.

Sudaryanto. Metode Linguistik Bagian Kedua: Metode dan Aneka Teknik Pengumpulan Data. Yogyakarta. Gadjah Mada University Press. 1988.

http://covid19.go.id diakses pada 26 April 2020 pukul 07.00 WIB. http://dunia.tempo.co/read/1319169/infeksi-

pertama-virus-corona-didugaterjadi-pada-17-

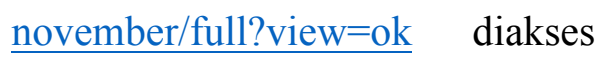
pada 26 April 2020 pukul 08.00 WIB.

http://kominfo.go.id/content/detail/25170/pe merintah-luncurkan-situs-resmicovid-19/0/berita diakses pada 26 April 2020 pukul 08.15 WIB.

http://www.kompas.com/tren/read/2020/03/1 $\underline{\text { 2/113008565/timeline-wabah- }}$ virus-corona-terdeteksi-padadesember-2019-hinggajadi?page $=3$ diakses pada 26 April 2020 pukul 08.15 WIB.

Kamus Besar Bahasa Indonesia (KBBI) Luar Jaringan (offline). Pusat Bahasa. Kementerian Pendidikan dan Kebudayaan. 2016. 